\title{
Scientific Cooperation in a German Polish Border Region in the Light of EU Enlargement
}

\author{
Jutta Günther a \\ Professor and Chair for Economics of Innovation and Structural Change, Faculty of Business Studies and \\ Economics, jutta.guenther@uni-bremen.de.

\section{Gresa Latifi ${ }^{\text {b }}$} \\ PhD Student, Department of Management, Economics and Industrial Engineering, gresa.latifi@polimi.it.
}

\section{Judyta Lubacha-Sember ${ }^{c}$}

$\mathrm{PhD}$ student, Faculty of Economics and International Relations, judyta@sember.pl.

\section{Daniel Töbelmann a}

Research assistant, Chair for Economics of Innovation and Structural Change, Faculty of Business Studies and Economics, daniel.toebelmann@gmx.de.

\author{
${ }^{a}$ University of Bremen, Hochschulring 4, 28359 Bremen, Germany \\ ${ }^{\text {b }}$ Polytechnic University of Milan, Via R. Lambruschini 4/b, 20156, Milan, Italy \\ 'Cracow University of Economics, Leszcze 14, 28-400 Pińczów, Poland
}

\begin{abstract}
$\mathrm{T}$

his paper evaluates the economic advantages and disadvantages of the Eastern expansion of the European Union for old and new EU member states, and introduces support programmes which aim to integrate regions on both sides of the border. It focuses especially on the development of cross-border scientific cooperation between Germany and Poland. An empirical study on the example of the Europa University Viadrina (EUV), a newly founded university in the GermanPolish border region, shows the extent of German-Polish cooperation based on co-publication activity. In our

small-scale empirical investigation for the Faculty of Business Administration and Economics of the EUV, we identified quite a number of co-publications between EUV staff and Polish colleagues. Most of them take place within the EUV, and many relate to cooperative work with scientific entities in both Poland and Germany. The entire intensity and frequency of cooperative scientific activities is, however, much broader than the publication analysis shows and offers scope for further integration with possible positive spillovers for the economic development as well.
\end{abstract}

Keywords: EU eastern enlargement; Central and Eastern European Countries (CEECs); economic development; cross-border scientific cooperation; border region; European University Viadrina (EUV); co-publication analysis; Germany; Poland.
Citation: Günther J., Latifi G., Lubacha-Sember J., Töbelmann D. (2017) Scientific Cooperation in a German Polish Border Region in the Light of EU Enlargement. Foresight and STI Governance, vol. 11, no 1, pp. 42-53. DOI: 10.17323/2500-2597.2017.1.42.53. 
A fter the collapse of the communist system in East Germany and Poland, enormous socioeconomic changes took place at the country and regional levels. East Germany quickly became part of the reunified Germany and thus of the EU in 1990. It was integrated in an already established system with all its formal institutions and benefitted from financial transfers within Germany and the EU. Poland, on the other hand, had to establish a market-based economic system from scratch, and its accession to the EU took place only 14 years after the beginning of transition towards a market economy. The predictions about the effects of the enlargement of the EU on old and new member states were manifold with positive and more sceptical expectations alike.

In 2004, the European Commission expected, that the eastern enlargement, also referred to as the fifth enlargement, would bring the following benefits [European Commission, 2003, p. 5]:

- "The extension of the zone of peace, stability and prosperity in Europe will enhance the security of all its peoples.

- "The addition of more than 100 million people, in rapidly growing economies, to the EU's market of 370 million will boost economic growth and create jobs, both in old and in new member states.

- "There will be a better quality of life for citizens throughout Europe as the new members adopt EU policies for the protection of the environment and the fight against crime, drugs and illegal immigration.

- "Enlargement will strengthen the Union's role in world affairs - in foreign and security policy, trade policy, and the other fields of global governance."

Nevertheless, there were also more sceptical voices about the enlargement process [Verdun, 2005, p. 14]:

- 'Enlargement might jeopardise the process of 'deepening';

- Sharing the budgetary means with the applicant states lowers the effectiveness of budget funds;

- Being sceptical about the applicant states ability to implement the EU acquis communautaire;

- Fear of mass migration from the accession countries to the old member states;

- Concern that the EU will no longer be governable with so many member states and without clear institutional and policy-making reforms."

For applicant countries, both political and economic reasons played a role. They could benefit from being a part of a larger community sharing similar norms and practices, and from gaining access to the common European market [Verdun, 2005]. Moravcsik and Vachudova pointed out that Central and Eastern European Countries (CEECs) faced the choice of taking part in the accession process due to the economic, institutional and geopolitical benefits of EU membership or of staying behind while others moved forward [Moravcsik, Vachudova, 2005].

There tends to be an agreement concerning the notion that EU integration and enlargement is an important process that leads to growth and economic development. However, such implications are not the same across countries. In this line of argumentation, Lejour et al. claims that this process leads only to small welfare increases in most older EU members whereas new members derive great advantages from the process [Lejour et al., 2001]. Epstein argues that this process will benefit the new countries that join the enlargement in particular [Epstein, 2014].

The border between the Eastern and Western parts of the European Union is a border between countries that belonged to fundamentally different economic systems until 1990. It is not surprising that there are lasting differences between the two sections of Europe, but the question remains for how long the former separation will be visible and, even more, how the East-West divergence can be overcome. ${ }^{1}$ One obvious perspective in this context would be to look at the border regions between Eastern and Western European countries and their cooperation activities. This will be attempted in this paper, with a focus on the German-Polish border and the potential for research cooperation.

In the following, we will set the scene through a brief introduction to the enlargement process including a discussion of the pros and cons and the effects of enlargement for the border regions. In this paper, we will focus on the Eastern enlargement. We will proceed with an elaboration upon the specific EU programmes that support cross border regional activities and economic development. After this, we will provide a small empirical analysis of the research cooperation induced by a newly founded university in the border region between Germany and Poland. Finally, we will draw conclusions and discuss further research topics.

${ }^{1}$ There is a large amount of literature on the convergence process between East and West Germany (e.g. [Udo, 2015; Heimpold, Titze, 2014; Aumann, Scheufele, 2011]). The convergence process between the East and West of Germany slowed down in the second half of the 1990s and has nearly come to an end now. It would be far beyond the scope of this article to go into this literature and analyses on East and West Germany. 


\section{Enlargement of the European Union}

The expansion of the EU is a widely discussed topic and relevant to several disciplines, such as economics, political science, sociology and law. In this study we focus on the economic aspects only. Indeed, this aspect was the initial reason why the EU was originally established.

The history of the European Union begins in 1951-1952, when the European Coal and Steel Community (ECSC) was founded in order to regulate the market for coal and steel in an attempt to solve economic problems in those sectors [Elvert, 2004]. In 1957-1958 the European Economic Community (EEC) was founded with the aim "to create a new politically stable and economically prosperous European order, which was supposed to be able to overcome the traditional tensions and conflicts between nation-states" [Elvert, 2004, p. 201]. Economic integration was seen as a way to secure peace. Since the Maastricht Treaty, which introduced the three pillars of the European Union (Economic and Monetary Union, Common Foreign and Security Policy, Justice and Home Affairs), the European Union started to be seen not only as an international economic organisation, but also as an organisation that supports democracy and rule of law [Curzon Price, Landau, 1999].

Over time, the alliance grew from the original six to the current 28 member states as a result of continued negotiations and enlargement agreements. ${ }^{2}$ Tebbe defines the process of enlargement as a joint endeavour in which potential candidate states are obliged to attain the EU's state of economic and political integration, the so-called "acquis communautaire" [Tebbe, 1994]. And vice versa, the EU is responsible for providing the relevant support for reaching the standard. From an institutional point of view, the enlargement of an organisation is, according to Schimmelfenning and Sedelmeier [Schimmelfenning, Sedelmeier, 2002], a process of gradual formal horizontal institutionalisation of the organisational rules and norms.

Due to the success of the former European Community (EC), the first enlargement took place in the year 1973 when Denmark, the United Kingdom, and Ireland joined the European community. This was followed up by Greece, which became a member in 1981, and Spain and Portugal, which joined the European community in 1986 [Preston, 1997]. The achieved depth of cooperation, particularly after the decision to sign the Maastricht Treaty in the year 1991 which aimed to create a single political union, motivated another round of enlargement in 1995 when Austria, Sweden, and Finland joined the European Union leading to 15 member countries.

Although the beginning was difficult, the EU became the most important means for providing prosperity on the continent, especially after the fifth and the greatest enlargement during which many Eastern European countries joined the agreement some 15 years after the collapse of communism. This unification is therefore considered the most radical break that ever occurred in the history of the EU [Moravcsik, Vachudova, 2002]. In 2004, the EU welcomed 10 new countries, most of them from Central and Eastern Europe to join the EU (Cyprus, Malta, Czech Republic, Estonia, Hungary, Latvia, Lithuania, Poland, Slovakia, and Slovenia) [Zeff, 2006].

The next enlargement of the EU led to two new member states: Romania and Bulgaria. These countries became the newest members of EU in 2007, followed by Croatia, which joined in 2008.

This "great European event" has been part of academic debates over the years (e.g. [Baldwin, 1995; Sjursen, 2002; Diez et al., 2006]), especially concerning the reasons why the EU intended to expand into Central and Eastern Europe. Baldwin argues that this decision was undertaken to achieve stronger political stability and long-term economic prosperity [Baldwin, 1995]. He furthermore overestimates the political reasons as compared to the economic interests of EU incumbents on newcomers. He writes that when an economically small region integrates with an economically large region, both gain benefits but the small region gains much more ${ }^{3}$, implying that the EU intended to integrate Eastern European countries to create more stability on the whole European continent.

Somewhat surprisingly, Epstein and Jacoby find that the enlargement of the EU has had more direct and far-reaching effects on CEECs' economies than on their democracies [Epstein, Jacoby, 2014]. For this reason, we will analyse the economic effects of the EU's eastern enlargement.

\section{Economic effects of the EU expansion for border regions}

The EU's eastern enlargement left in its wake many discussions, expectations as well as concerns. The changing of the borders from the EU15 to the EU28 raised the attention of economists to the effects

\footnotetext{
${ }^{2}$ When writing this article, the referendum over the membership of Britain in the EU took place the country. The majority voted for an exit from the EU and negotiations on this subject are still ongoing.

${ }^{3}$ Baldwin's conclusions were based on the work by Francois and Shiells [Francois, Shiells, 1992] who described the impact of NAFTA on Mexico and US, so he made some tentative analysis-by-analogy assuming that a similar situation occurred in EU as well.
} 
of such an expansion, since the new members were anticipated to play a crucial role within these new spatial dynamics [Niebuhr, 2008]. This becomes even more important when one realizes that 11 out of the 13 new member countries are post-communist economies which gained their independence from the Soviet bloc between 1989 and 1991. Nevertheless, the main concern after the formalisation process of enlargement was the economic and structural divergences between the old and new member states.

Early contributions in economic literature relating to the enlargement process of the EU focus on the possible growth effects for the member countries (e.g., [Bröcker, Jägre-Roschko, 1996; Bröcker, 1998]). In a quantitative analysis, Bröcker and Jägre-Roschko [Bröcker, Jägre-Roschko, 1996] estimate the regional effects expected to be caused by the integration of the CEECs. In particular, they focused on the effects of the enlargement on the lagging regions of the EU. They found that the trade of lagging regions would not be harmed due to the enlargement, and that there are no grounds for concern. In contrast, due to the geographic proximity of Greece ${ }^{4}$, they stand to benefit from the Eastern expansion by having the opportunity to increase their new commercial links with new members from the East. Baldwin et al. [Baldwin et al., 1997] in their analysis of the costs and benefits of the eastern enlargement estimated that real income in the CEECs would increase by 18.8 percent in the long-run. Lejour et al. [Lejour et al., 2001] made an attempt to estimate the economic consequences of the enlargement of the European Union, taking into consideration three dimensions of enlargement: a customs union, an internal market, and the free movement of labour. It was found that the Eastern European states' accession to the EU would be of significant importance, and that GDP per capita would increase by more than $8 \%$ in the long$\operatorname{run}^{5}$. For the EU15 countries, there were no significant changes, however for Germany it was found that GDP per capita could slightly decrease due to migration.

Later on, Brülhart et al. [Brülhart et al., 2004] also investigated the economic effects of the enlargement at the regional level and the consequences of changes in market access. Niebuhr and Stiller [Niebuhr, Stiller, 2002] discuss the effects of the enlargement on the regions which were located on the borders of new member states. They argue that border regions might have an advantage in attracting resources hence the above-average benefits. However, there still is no clear conclusion either from theory or from empirical findings about the spatial effects of integration, since in some specific circumstances border regions might lose and sometimes national borders are the main barriers to economic relationships. The consequences of the eastern enlargement for the EU and CEECs are visible in various areas. In economic research, the two most relevant topics are economic convergence at the national and regional levels and migration movements after the EU's eastern expansion.

Oblath et al. [Oblath et al., 2015] when analysing beta and sigma convergence showed in their preliminary results that both types of convergence have been visible within the EU26 since 2000. ${ }^{6}$ Forgo and Jevcak [Forgo, Jevcak, 2015] confirmed that the CEECs (10 new member states) achieved real and nominal convergence vis-à-vis Eurozone countries ${ }^{7}$. Also, Koh [Koh, 2015] found that economic convergence takes place in new member states as compared to old member states. ${ }^{8}$. A quite different picture can be found at the regional level. Mikulić et al. [Mikulić et al., 2013], in analysing regional beta convergence in new member states, confirmed that beta convergence can be found at the national level but that on the regional level, the convergence speed is lower. Similar results were obtained by Pukeliene and Butkus for NUTS-3 level analysis [Pukelienè, Butkus, 2012]. Also Monastiriotis confirmed that "regional evolutions continue to be on the whole divergent, with a pattern of convergence at the middle- and lower-ends of the distribution and a slower tendency for club formation at the higher end, and thus overall an increasing trend of polarization" [Monastiriotis, 2011, p. 23].

Considering the great importance of migration on the macroeconomic stability of a country, we should briefly shed some light on the effects of the enlargement on the propensity towards migration. Generally it is found that the enlargement of the EU in May 2004 was followed by an increase of migration from the poorest Central and Eastern European regions to richer regions in the EU15 [Barrell et al., 2010], but there was no evidence for a negative effect from migration on wages or employment in the older member

\footnotetext{
${ }^{4}$ Proximity to Bulgaria in this situation and with forthcoming potential candidates (Macedonia, Bosnia and Herzegovina, Kosovo, Albania, Serbia etc.)

${ }^{5}$ Henrekson et al. [Henrekson et al., 1997] when analysing the effects of European integration on economic growth of EU-15, found that European Community membership may increase growth rates (by about $0.6-0.8$ percentage points), and that technology transfer is the main mechanism through which membership can affect growth.

${ }^{6}$ The paper [Oblath et al., 2015] discusses some methodological issues regarding to measures of comparative growth performance (which can influence the interpretation of the results). Beta convergence refers to "a statistically significant negative relationship that exists between the "initial" per capita GDP of individual countries on the one hand, and their per capita growth rates on the other", while sigma convergence refers to "the cross-section dispersion in levels of income declines over time" [Oblath et al., 2015, p. 26].

7 Authors probably analysed the beta-convergence process, but the type of convergence was not directly mentioned in the text.

${ }^{8}$ Koh also analysed social cohesion processes in new member states in his paper [Koh, 2015].
} 
countries [Kahanec, Zimmermann, 2007]. The macroeconomic impact of migration is expected to be more strongly visible in English-speaking countries of the EU15 rather than, for example, in Germany or Austria, which were regarded as attractive destinations for a large migration flows [Boeri, Brucker, 2001]. The United Kingdom, which is expected to be more affected by migration, experienced a period of low productivity growth ${ }^{9}$. Generally, the high outflow migration from new member states predicted by Boeri [Boeri, 2002] did not take place. Around 2.2 million residents from the CEECs migrated to Western European countries between 1988 and 2012 [Balazs et al., 2014], which equals 2\% of total CEECs-10 population in the year 2012. ${ }^{10}$

Concerned about the impact of the EU enlargement on border regions, Niebuhr [Niebuhr, 2008] measured the enlargement's effects, this time with a special focus on the border regions in the EU27. Firstly, he concedes that the greater benefits of the EU's expansion are seen in the new member states rather than in the EU15 (important signal toward cohesion). This finding is categorically opposed by Ellison [Ellison, 2006] who states that the benefits of West European states are clearly underestimated ${ }^{11}$. Secondly, Niebuhr [Niebuhr, 2008] argues that border regions indeed realise higher integration benefits than non-border regions, demonstrating that there are certainly above-average benefits for these newer members [Niebuhr, Stiller, 2002; Niebuhr, 2006].

Overall, from the literature and EU reports, it can be concluded that the enlargement positively affected the economies of the EU in general and especially the new member states. Furthermore, border regions of the EU15 are considered to benefit the most from this process.

\section{EU financial support programmes for border regions}

The cross-border cooperation between countries of the EU has always been one of the priorities of the EU. A trans-frontier region is a region inherent in geography, history, ecology, ethnic groups, and economic possibilities, but disrupted by the sovereignty of the governments ruling on either side of the frontier [CoE, 1995].

Through various programmes, the EU has attempted to intensify the cooperation within border regions of the EU. In the following, we would like to discuss the specific EU support programmes for border regions and their relevance for successful cooperation on the EU's East-West border.

Cross-border cooperation programmes are aimed at developing a shared space and at sharing, integrating and improving quality of life. Knowledge, infrastructure, and other assets can be shared by using crossborder programmes. The improvement of quality of life includes programmes aimed at environmental protection, healthcare services or access to the labour market. Within the programmes, all types of partners are welcome: ministries, small municipalities, universities, NGOs and SMEs. The European Territorial Cooperation has been established as a part of a policy of cohesion. The first INTERREG programme started in 1990. INTERREG II and III were undertaken in the years 1994-1999 and 20002006 [European Commission, 2011]. INTERREG IV covered the years 2007-2013. This policy was set up by the European Commission and it aims to foster cooperation between EU regions, with a particular focus on border zones [O'Dowd, 2002]. For the years 2014-2020 INTERREG EUROPE was launched as part of the Europe 2020 strategy. It is being used as an instrument for the implementation of a cohesion policy. The following objectives are addressed by INTERREG EUROPE programme [European Commission, 2015]:

1. Strengthening research, technological development and innovation

2. Enhancing the competitiveness of small and medium-sized enterprises

3. Supporting the shift towards a low-carbon economy in all sectors

4. Protecting the environment and promoting resource efficiency.

Another category of programmes effective during the period of 1997-2003 and established by the European Commission for inter-regional cooperation between the EU and CEECs is that of OUVERTURE/ECOS. It focused on local economic development in the sense of administrative and regional urban planning [Gruchman, Walk, 1997]. Countries within the EU that had at least two territorial units were eligible for this programme.

\footnotetext{
${ }_{9}$ Duffy et al. [Duffy et al., 2005] found that the immigration level has an impact on welfare implications for residents and affects the aggregate productivity, like the case in the UK, which experienced a period of slow productivity growth.

${ }^{10}$ Total CEECs-10 population figures were calculated based on Eurostat database (online data code: demo_pjan, http://appsso. eurostat.ec.europa.eu/nui/show.do?dataset=demo_pjan\&lang=endemo_pjan, last accessed on 05.07.2016).

${ }^{11}$ The author also found that the overestimation of the benefits of new EU members and underestimation of their costs were irrational. For more information see [Ellison, 2006].
} 
The additional possibility of benefiting from another Action Programme supporting the cooperation between local and regional territorial units of at least three EU countries in the Action Programme for Exchange of Experience (PEE). Its main focus is in the field of know-how exchange in the implementation of EU policies regarding public administration, transport, applied research, universities and enterprises, local resources, energy and the environment [Gruchman, Walk, 1997].

There were also specific programmes in support of tourism and cross-border environmental policies such as LIFE [Gruchman, Walk, 1997] which started in the year 1992. In 2007, according to the new regulation (Regulation (EC) No 614/2007) ${ }^{12}$, the LIFE+ programme became the successor of the LIFE programme. It is divided into three components: Nature \& Biodiversity; Environmental Policy \& Governance; Information \& Communication. For the years 2014-2020, the Programme for the Environment and Climate Action (LIFE Programme) was established (Regulation (EU) No 1293/2013) ${ }^{13}$. Besides the aforementioned programmes, a particularly important programme for the Polish-German border regions is RETEX, which focuses on the textile and clothing industry. Finally, the original programme, PHARE, and its two sub-programmes TEMPUS and STRUDER were specifically designed for the assistance of Eastern European countries in their transition to market economies [Cunderliková, 2007].

For the years 2007-2013, the Cross-Border Cooperation Operational Programme between Poland (Lubuskie) and Germany (Brandenburg) was approved by the European Commission. The main objective of the programme was the reduction of the inconvenience caused by the location of the regions' borders and the joint development of the regions.

Operational objectives of the programme were the following [Europäischen Kommission, 2008]:

1. Improvement of infrastructure and environmental protection.

2. Development of economic relations and cooperation of scientific and economic sectors.

3. Support of the development of human capital and cross-border cooperation.

\section{The expansion's impact on Polish-German border regions}

The enlargement of the EU and integration of Poland had economic implications for both Poland and Germany, especially in the regions along the border. Reflecting the historical tensions between the two countries, we explore the changes of cooperation activities over the years. In 1945, as a consequence of the Second World War, the two rivers Oder/Odra and Neisse/Nysa became heavily guarded dividing lines between the German Democratic Republic (GDR) and Poland. As a consequence, there was little opportunity for direct contact or local cooperation between communities and regions [Gruchman, Walk, 1997].

Over time, the GDR, due to a shortage of manpower, encouraged people from Poland to work in large industrial plants close to the border. The effect of commuting to work became particularly significant in cities like Guben/Gubin or Görlitz/Zgorzelec, both located close to the river Neisse/Nysa. In the 1970s, there was a short period of freedom of mobility between both countries, the border could be crossed without a passport and visa. However, until 1989, when socialism in the GDR and Poland collapsed, cooperation between the two countries faced many obstacles and not very many opportunities for transfrontier synergy effects and development [Gruchman, Walk, 1997].

Only after the changes in 1989 did administrative entities, economic and social institutions, enterprises and local governments emerge on both sides of the border to institutionalize mutual economic and social cooperation. Starting, for example, from the launch of Neisse-Nysa Euroregion in 1992 followed by Pomerania Euroregion, Spree-Neisse-Bober in 1993, Pro-Euorpa Viadrina Euroregion in 1993. These initiatives aimed to establish and intensify cooperation in many fields, especially industry, innovation, agriculture, tourism, science, culture, and sports [Gruchman, Walk, 1997].

Later, after the efforts undertaken to meet the Copenhagen criteria as a prerequisite to join the EU, the accession process, and more than 10 years of being part of the EU, things have changed substantially, especially for Poland. In being a neighbour of Germany, one of the founding countries of the EU, Poland is the neighbour of an economically strong and relatively large country. This has its advantages and disadvantages. Unfortunately, we have found little evidence and very few robust figures related to the effects and consequences of Poland's integration into the EU, specifically along the border regions of both countries. However, on the Polish side, it is recognized that the Polish regions along the border

\footnotetext{
${ }^{12}$ Regulation (EC) No 614/2007 of the European Parliament and of the Council of 23 May 2007 concerning the Financial Instrument for the Environment (LIFE+).

${ }^{13}$ Regulation (EU) No 1293/2013 of the European Parliament and of the Council of 11 December 2013 on the establishment of a Programme for the Environment and Climate Action (LIFE) and repealing Regulation (EC) No 614/2007.
} 
with Germany are rendered particularly attractive for foreign and local investments due to the historical development of this part of Poland and due also to the accession of Poland to the EU. The importance of border regions for the economic development of Poland remains a challenge for the eastern part of the country, where the lack of investors is easily recognised [Cieślik, 2004].

On the other hand, there is little evidence regarding workers' mobility, which started to be a challenge for Poland after its accession to the EU. Generally, the population of Poland is declining. After 3 years of membership in the EU, the number of Polish workers (especially qualified workers) looking for employment in EU15 countries rose from 1 million to 2.3 million [WPBS, 2012]. "Before Poland's accession to the EU, Germany (37\% of all emigrants) and the United States (20\%) were the most common destinations chosen by Polish emigrants. After 2004, Poles most willingly went to EU member states: the UK (30\%), Germany (23.5\%), Ireland (5.5\%), Italy (4.5\%) and the Netherlands (4.5\%) [CSO, 2012]. At the same time, the rate of emigration to the US dropped to 12\%" [Kałużýska et al., 2014, p. 197]. It has been observed in the past ${ }^{14}$, that Polish migration to Germany was characterised by short-term, and back-and-forth mobility, without the will to settle down in Germany [Anacka, Figel, 2012]. As of 2011, Statistisches Bundesamt counted 468,481 Poles or $6.4 \%$ of all foreigners in Germany [Statistisches Bundesamt, 2011]. Their median age is 37.3 years and they stay for an average of 9.7 years. According to other estimates, the number of Poles with a migration background is about 1.3 million people and they mostly work in construction, manufacturing, healthcare, restaurants and trade [Eichhorst, Wozny, 2012, p. 4].

In the field of academic collaboration between Germany and Poland, an important initial step likely to impact collaboration both in science and the economy was the foundation of the European University Viadrina (EUV) in Frankfurt in the year 1992, one third of the student body is comprised of Polish students. On the other side of the border, in Słubice, the Collegium Polonicum was established as a part of EUV [Gruchman, Walk, 1997].

The founding of the EUV and Collegium Polonicaum, however, is not the starting point of GermanPolish scientific collaboration. Glänzel and Wintherhager [Glänzel, Wintherhager, 1992] have found results of the collaboration in the realm of academic research between eastern European countries (Hungary, Poland and Czechoslovakia), Germany and other members of the EU in 1980-1989. German scientists (compared to other scientists of EU member states) played an important role as co-authors with the three eastern countries, particularly with Poland ${ }^{15}$. Nevertheless, they did not deal with the question as to whether this relatively strong link between the two countries was because of being in the same border area.

Later on, Braun and Glänzel [Braun, Glänzel, 1996] also identified increasing cooperation between Germany and Poland during the period of 1984-1993. In comparison with other EC members, Germany remains the main collaboration partner of Poland and other Eastern European countries, such as Hungary and Romania. Generally, they did not find a clear justification for the German-Polish scientific cooperation being due in large part to the spatial proximity of these two countries. On the contrary, they state that the two countries substantially increased international scientific cooperation as a result of an increase in contracts on basic research over the course of the transition during the nineties. Due to the economic problems that Poland was going through, international cooperation in research during the 1990s was mainly viewed as a channel through which academia could get financial support from outside the country [Stefaniak, 1998].

In the following, we will present the results of an explorative empirical study into the cross-border research relationships of scientists from the European University Viadrina and scientists from Poland. Our focus is the intensity of relations expressed in scientific co-publications.

\section{Research cooperation in a Polish-German border region: the case of Viadrina}

The persistence in increasing the depth of cooperation between Poland and Germany, especially after the foundation of the European University Viadrina (EUV), shapes our paper's focus. Since it is difficult to find scientific evidence about whether or not the impact of the foundation of the university is positive or negative, we carry out a small primary data collection and analysis.

Our interest was to identify the cooperation between Polish and German scientists on the example of the discipline of economics. Henceforth, we run an analysis based upon the available information

\footnotetext{
${ }^{14}$ Migration until the year 2006 was analysed by [Anacka, Figel, 2012].

${ }^{15}$ Glänzel et al [Glänzel et al., 1999] have also measured the rate of citations impact of the three
} 


\section{Figure 1. Number of Polish and other international employees by departments of the Faculty} of Business Administration and Economics, EUV

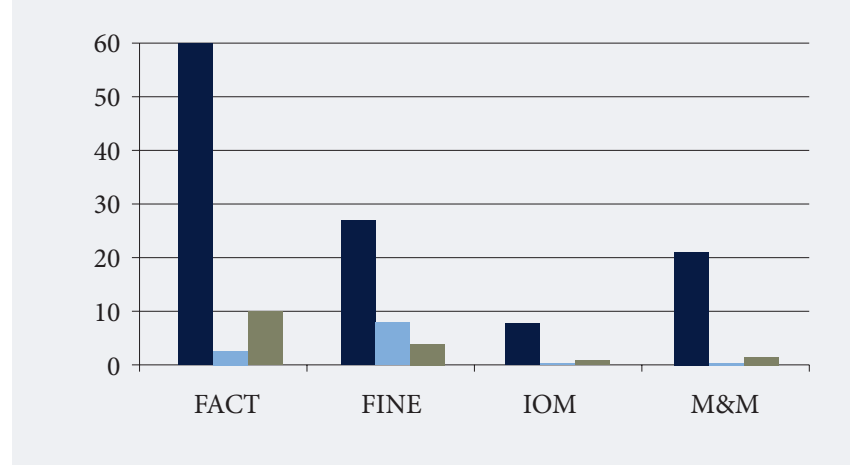

- Total number of employees

- Polish employees

- Other international employees

Note: Hereinafter in the figures the following acronyms of departments are used: FACT - Finance, Accounting, Controlling \& Taxation; FINE - Finance \& International Economics; IOM - Information \& Operations Management; M\&M - Management \& Marketing. The figures compiled by the authors using data from the University Viadrina website (https://www.wiwi.europa-uni.de/en/lehrstuhl/index. html, last accessed 05.07.2016).

on the university's homepage of the four departments of the Faculty of Business Administration and Economics: Finance, Accounting, Controlling \& Taxation (FACT), Finance \& International Economics (FINE), Information \& Operations Management (IOM) and Management \& Marketing (M \& M). Each department consists of at least two professorships (chairs) with a team of research assistants. We investigated the research of each professorship, i.e., the work of each chair of the Faculty of Business Administration and Economics. From the full list of publications, co-publications were identified, and from them co-publications with Polish co-authors ${ }^{16}$. The purpose of this is to identify the intensity of cooperation with different Polish co-authors, both before and after Poland's accession to the EU.

Firstly, we identified the overall number of Polish and international academic employees in each department in order to see the relationship of each one with Polish academics. Secondly co-publications with Polish co-authors were counted. Polish co-authors were identified as belonging to three groups: (i) Polish co-authors employed at EUV, (ii) Polish co-authors employed at research entities or in the business sector in Poland, and (iii) Polish co-authors employed at other than EUV German research entities. In the case of co-publications with 2-3 co-authors from different groups, they were assigned to each type of group. Therefore, the sum of co-publications with co-authors from the three groups mentioned above are not equal to the number of "All Polish co-publications". Polish co-authors and employees were identified based on the following scheme: first all Polish-written surnames were selected, then curriculum vitae on universities' website were analysed. If a person was born or educated (in the early stage) in Poland he or she was counted as Polish employee or co-author. The research entity with which the co-author is affiliated was identified using Scopus, Web of Science, or the text of publications when information about the authors are provided. In case of co-authors employed in the business sector, internet-based sources, such as LinkedIn, were used.

Based on this analysis, it can be stated, that every department employs international employees, most were employed by the department of "Finance, Accounting, Controlling and Taxation" (FACT). Out of the four, two departments employ Polish researchers. Here the FACT department can be named again, with three Polish employees out of 59 employees in total (i.e., 5\%), and the FINE department with eight Polish employees out of 27 in total (i.e. 30\%). The high share in the case of FINE is due to the "Professorship for Interdisciplinary Polish Studies", which employs seven Polish researchers, which is half of its team. ${ }^{17}$

Referring to publications with Polish co-authorships, we found, that two departments cooperate with Polish authors. Similar to the results of the employee analysis above, for the FACT and FINE departments it is possible to determine publications in cooperation with Polish co-authors as shown in Figure 2. With 128 co-publications with Polish co-authors, which is around $16.5 \%$ out of the entire number of the department's documented publications, FACT can be described as the most active department in cooperating with Polish authors. The largest number derives from the "Professorship in Taxation and Auditing", with 120 Polish contributions. For FINE, eight Polish co-publications out of 228 co-publications in total can be determined. Here again the largest part of cooperative activity is due to the chair of "Professorship for Interdisciplinary Polish Studies", to which are attributable six Polish co-publications.

\footnotetext{
${ }^{16}$ Authors focus in the text on Polish-German cross-border cooperation, therefore other co-publications were not detailed investigated in detail, although data about them were also collected.

${ }^{17}$ The "Professorship for Interdisciplinary Polish Studies" is closely connected to the centre for Interdisciplinary Studies on Poland (ZIP). The chairman is the head of ZIP.
} 


\section{Figure 2. Number of co-publications and co-publications with Polish authors by departments of the} Faculty of Business Administration and Economics, EUV

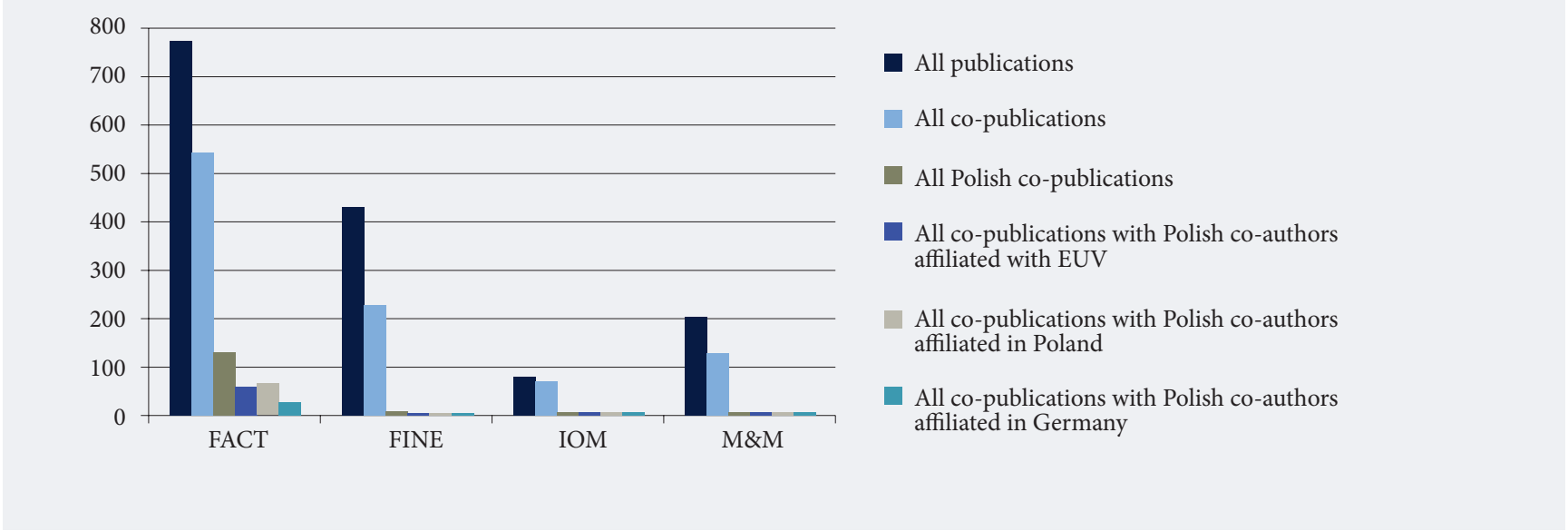

In Figure 3, it can be seen that in the FACT and FINE departments a large number of the Polish copublications are in collaboration with EUV-affiliated Polish authors. However, the number of coauthors affiliated with Polish organisations is even larger in both departments. The smallest number are publications with Polish co-authors affiliated with other German research organisations. For the departments "Information \& Operations Management" (IOM) and "Management \& Marketing" (M \& M) neither Polish employees nor Polish co-publications were reported.

To further analyse the Polish co-publications (as many as 136 in total), we run a network analysis to show the intensity of cooperation between EUV (represented by the Faculty of Business Administration and Economics) and other selected institutions. In Figure 4, the number of co-authors affiliated with a given research entity is represented by the size of the node, and the number of co-publications with the given institution is represented by the width of the links. For example, EUV has 51 co-publications with the Warsaw School of Economics (the width of the link), and one co-author affiliated with the Warsaw School of Economics cooperate with EUV (the size of the node).

It can also be shown in Figure 4 that there is strong co-authorship activity within the EUV shown by the width of the link which is attributable to the number of co-publications (62) with Polish EUVaffiliated employees (14 co-authors). Scientists from EVU are also co-publishing with Polish authors from institutions in Poland, such as the Warsaw School of Economics and others, although the number of co-publications is often very small. Several Polish co-authors are affiliated with research entities in Germany other than EUV (6 co-authors) or with the business sector in Poland (7 co-authors).

\section{Conclusion}

The system breakdown in 1990 triggered a deep transition and restructuring process in East Germany and Poland. While in East Germany the EU accession took place automatically with the German re-

Figure 3. Number of co-publications with Polish authors by departments of the Faculty of Business Administration and Economics, EUV

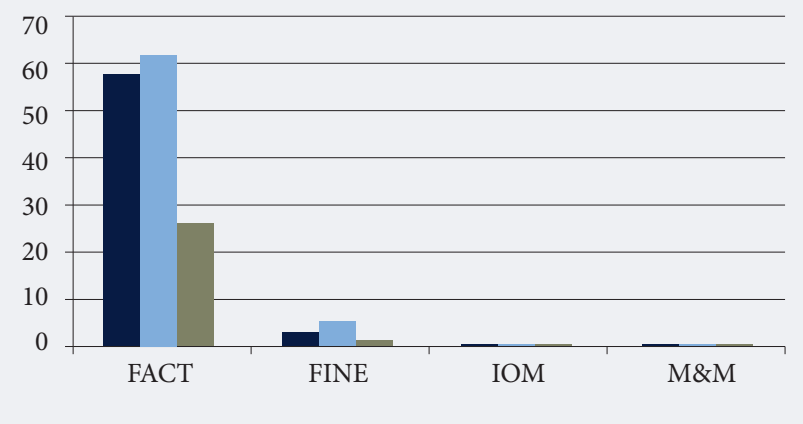

All co-publications with Polish authors affiliated with EUV

All co-publications with Polish authors affiliated in Poland

All co-publications with Polish authors affiliated in Germany 


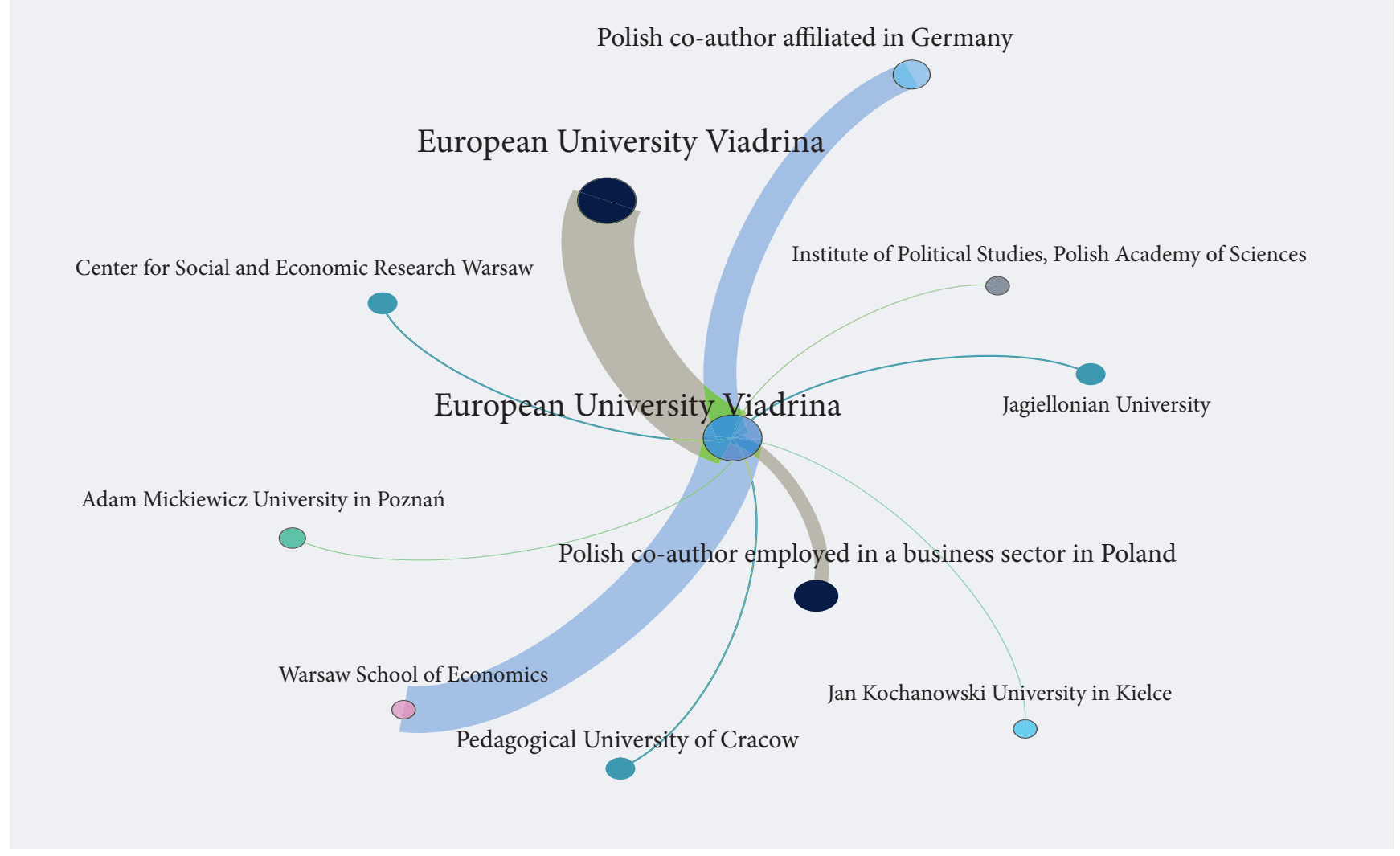

unification, Poland became a member of the EU only much later in the year 2004. In the early stage of the transition, both countries (or region, in case of East Germany) were strongly occupied with the restructuring and reorientation in nearly every field of economic and scientific activity. However, the EU supported cross-border activities in order to integrate the regions and people working and living there from the very beginning. Cross-border activities related to closer economic integration appear in many areas and forms, among them research cooperation. We focused in this article on research cooperation in the German-Polish border region in which a new university was founded after the changes of the year 1990, not least with the objective to strengthen regional and overall scientific integration between Germany and Poland. The European University Viadrina (EUV), located on the German side of the border in Frankfurt/Oder, is thus a unique case together with the Collegium Polonicum, located on the Polish side of the border in Słubice. As many as one third of the student body at EUV are from Poland, which represents a large share and expresses the success of the cross-border-oriented university. In this paper, we also shed some light on the question of scientific cooperation which needed to be established with the foundation of the university and the overall re-orientation process in the early 1990s. Scientific cooperation can take place in many different forms, reaching from the very informal and implicit activities to formally institutionalised projects. To get a first impression as to whether joint German-Polish activities have been established at all and to which extent, we looked at co-publications. The co-publications express an already advanced stage of research cooperation since they go beyond just informal contacts and document a clear scientific product. In our small-scale empirical investigation for the Faculty of Business Administration and Economics of the EUV, we identified quite a number of copublications between EUV staff and Polish colleagues. Most of them take place within the EUV, and many relate to cooperative work with research entities in Poland. A network of scientific contacts has been created since the early 1990s. The intensity and frequency of cooperative research activities is, however, much broader than the publication analysis shows and offers opportunities for further integration with possible positive spillovers for economic development as well.

We thank Mahmood Shubbak (Faculty of Business Studies and Economics at the University of Bremen) for his kind assistance in running the network analysis and Marcel Lange (Faculty of Business Studies and Economics at the University of Bremen) for his kind assistance in data collection and formatting. 


\section{References}

Anacka M., Fihel A. (2012) Return Migration to Poland in the Post-accession Period // EU Labour Migration in Troubled Times. Skills Mismatch, Return and Policy Responses / Eds. B. Galgoczi, J. Leschke, A. Watt. London / New York: Routledge. P. 143-168.

Aumann B., Scheufele R. (2011) Is East Germany Catching Up? A Time Series Perspective // Post-Communist Economies. Vol. 22. No 2. P. 177-192.

Balazs P., Bozóki A., Catrina Ş., Gotseva A., Horvath J., Limani D., Radu B., Simon Á., Szele Zselyke Á., PerlakyTóth T.K. (2014) 25 years after the fall of the Iron Curtain. The state of integration of East and West in the European Union. Brussels: European Commission.

Baldwin R.E. (1995) The Eastern Enlargement of the European Union //European Economic Review. Vol. 39. No 3. P. 474-481.

Baldwin R.E., Francois J.F., Portes R. (1997) The costs and benefits of eastern enlargement: The impact on the EU and Central Europe // Economic Policy. Vol. 12. P. 125-176.

Barrell R., Fitz Gerald J., Riley R. (2010) EU Enlargement and Migration: Assessing the Macroeconomic Impacts // Journal of Common Market Studies. Vol. 48. No 2. P. 373-395.

Boeri T. (2002) Who's Afraid of the Big Enlargement Economic and Social Implications of the European Union's Prospective Eastern Expansion. CEPR Policy Paper No 7. London: Centre for Economic Policy Research.

Boeri T., Brücker H. (2001) Eastern Enlargement and EU-Labour-Markets: Perceptions, Challenges and Opportunities. IZA Discussion Paper Series No 256. Bonn: Institute of Labor Economics (IZA).

Braun T., Glänzel W. (1996) International Collaboration: Will It Be Keeping Alive East European Research? // Scientometrics. Vol. 36. No 2. P. 247-254.

Bröcker J., Jäger-Roschko O. (1996) Eastern Reforms, Trade, and Spatial Change in the EU // Papers in Regional Science. Vol. 75. No 1. P. 23-40.

Bröcker J. (1998) How would an EU-membership of the Visegrád-countries affect Europe's economic geography? EU-membership of the Visegrád-countries // The Annals of Regional Science. Vol. 32. No 1. P. 91-114.

Brülhart M., Crozet M., Koenig P. (2004) Enlargement and the EU Periphery: The Impact of Changing Market Potential. HWWA Discussion Paper No 270. Oxford: Blackwell Publishing.

Cieślik A. (2005) Location of Foreign Firms and National Border Effects: The Case of Poland // Tijdschrift voor Economische en Sociale Geografie. Vol. 96. No 3. P. 287-297.

CoE (1995) Manuel de coopération transfrontaliére à l'usagedes collectivités locales et regionals en Europe. Strasbourg: Council of Europe.

CSO (2012) Population and Migration Estimates April 2012 (with revisions from April 2007 to April 2011). Dublin: Central Statistics Office.

Cunderlikova M. (2007) The European Union Phare Programme. Режим доступа: http://www.nbs.sk/_img/ Documents/BIATEC/BIA01_07/13.pdf, дата обращения 23.06.2016.

Curzon Price V., Landau A. (1999) Introduction. The Enlargement of the European Union: Dealing with Complexity // The Enlargement of the European Union. Issues and Strategies / Eds. V. Curzon Price, A. Landau, R.G. Whitman. London / New York: Routledge. P. 10-24.

Diez T., Stetter S., Albert M. (2006) The European Union and Border Conflicts: The Transformative Power of Integration // International Organisation. Vol. 60. No 3. P. 563-593.

Duffy D., FitzGerald J., Kearney I. (2005) Rising House Prices in an Open Labour Market // Economic and Social Review. Vol. 36. P. 251-272.

Eichhorst W., Wozny F. (2012) Migration Policies in Germany. Research Reports Recommendations. Warszawa: Institute of Public Affairs.

Ellison D. (2006) Divide and Conquer: The European Union Enlargements Successful Conclusion? // International Studies Review. Vol. 8. No 1. P. 150-165.

Elvert J. (2004) A fool's game or a comedy of errors? EU enlargements in comparative perspective // European Union Enlargement: A Comparative History / Eds. W. Kaiser, J. Elvert. London; New York: Routledge. P. 201-221.

Epstein R.A. (2014) Overcoming "Economic Backwardness" in the European Union // Journal of Common Market Studies. Vol. 52. No 1. P. 17-34.

Epstein R.A., Jacoby W. (2014) Eastern Enlargement Ten Years On: Transcending the East-West Divide? // Journal of Common Market Studies. Vol. 52. No 1. P. 1-16.

European Commission (2003) Enlargement of the European Union. An historic opportunity. Brussels: European Commission.

European Commission (2011) European Territorial Cooperation. Building Bridges Between People. Brussels: EC Directorate General for Regional Policy.

Europäischen Kommission (2008) Operationelles Programm zur grenzübergreifenden Zusammenarbeit Polen (Wojewodschaft Lubuskie) - Brandenburg 2007-2013 im Rahmen der "Europäischen territorialen Zusammenarbeit”. Genehmigt von der Europäischen Kommission am 25.03.2008. Режим доступа: http://bit. ly/2j2yPGl, дата обращения 15.07.2016.

Forgo B., Jevcak A. (2015) Economic Convergence of Central and Eastern European EU Member States over the Last Decade (2004-2014). European Economy Discussion Paper No 001 (July 2015). Brussels: European Commission.

Francois J.F., Shiells C.R. (1994) AGE Models of North American Free Trade // Modelling Trade Policy: Applied General Equilibrium Assessments of North American Free Trade / Eds. J.F. Francois, C.R. Shiells. New York: Cambridge University Press. P. 3-44.

Glänzel W., Winterhager M. (1992) International collaboration of three East European countries with Germany in the sciences, 1980-1989 // Scientometrics. Vol. 25. No 2. P. 219-227. 
Glänzel W., Schubert A., Czerwon H.J. (1999) A Bibliometric Analysis of International Scientific Cooperation of the European Union (1985-1995) // Scientometrics. Vol. 45. No 2. P. 185-202.

Gruchman B., Walk F. (1997) Trans-boundary Cooperation in the Polish-German Border Region // Borders and Border Regions in Europe and North America / Eds. P. Ganster, D.E. Lorey. Lanham; Boulder; New York; Toronto; Oxford: SR Books. P. 177-191.

Heimpold G., Titze M. (2014) Development in East Germany since German Unification. Results, Shortcomings and Implications for Economic Policy // Competitiveness in the European Economy, Routledge Studies in the European Economy / Eds. S. Collignon, P. Esposito. London; New York: Routledge. P. 184-196.

European Commission (2015) INTERREG EUROPE 2014-2020. CCI 2014 TC 16 RFIR 001. Cooperation Programme document. Final. Brussels: European Commission.

Kałużyńska M., Karbownik P., Burkiewicz W., Janiak K., Jatczak M. (eds.) (2014) Poland's 10 years in the European Union. Warszawa: Ministry of Foreign Affairs.

Kahanec M., Zimmermann K.F. (2009) Migration in an enlarged EU: A challenging solution? (European Economy, Economic Papers 363, March 2009). Brussels: European Commission.

Koh H. (2015) Convergence and divergence - 10 years since EU enlargement // Transfer. Vol. 21. No 3. P. 285311.

Lejour A.M., De Mooij A.R., Nahuis R. (2001) EU enlargement: Economic implications for countries and industries. CPB Document No 011. Hague: CPB Netherlands Bureau for Economic Analysis.

Mikulić D., Lovrinčević Z., Galić Nagyszombaty A. (2013) Regional Convergence in the European Union, New Member States and Croatia // South East European Journal of Economics and Business. Vol. 8. No 1. P. 7-19.

Monastiriotis V. (2011) Regional Growth Dynamics in Central and Eastern Europe. LSE 'Europe in Question' Discussion Paper Series, LEQS Paper No 33/2011. London: London School of Economics.

Moravcsik A., Vachudova A.M. (2005) Preferences, power and equilibrium. The causes and consequences of EU enlargement // The Politics of European Union Enlargement. Theoretical Approaches / Eds. F. Schimmelfennig, U. Sedelmeier. New York: Routledge. P. 198-212.

Moravcsik A., Vachudova A.M. (2002) National Interests, State Power, and EU Enlargement // East European Politics and Societies. Vol. 17. No 1. P. 42-57.

Niebuhr A. (2008) The Impact of EU Enlargement on European Border Regions // International Journal of Public Policy. Vol. 3. No 3. P. 163-186.

Niebuhr A., Stiller S. (2002) Integration Effects in Border Regions - A Survey of Economic Theory and Empirical Studies. Paper presented at the 42nd Congress of the European Regional Science Association "From Industry to Advanced Services - Perspectives of European Metropolitan Regions", August 27th - 31st, 2002, Dortmund.

Niebuhr A. (2006) Spatial Effects of European Integration: Do Border Regions Benefit Above Average? // The Review of Regional Studies. Vol. 36. No 3. P. 254-278.

Oblath G., Palocz E., Popper D., Valentinyi A. (2015) Economic convergence and structural change in the new member states of the European Union (IE CERS Discussion papers MT-DP - 2015/44). Budapest: Institute of Economics, Centre for Economic and Regional Studies, Hungarian Academy of Sciences.

O’Dowd L. (2002) The Changing Significance of European Borders // Regional \& Federal Studies. Vol. 12. No 4. P. 13-36.

Preston C. (1997) The Enlargement and Integration of the European Union: Issues and Strategies. London; New York: Routledge.

Pukeliene V., Butkus M. (2012) Evaluation of Regional $\beta$ Convergence in EU Countries at NUTS3 Level // Ekonomika. Vol. 91. No 2. P. 22-37.

Sjursen H. (2002) Why expand?: The question of legitimacy and justification in the EU's enlargement policy // Journal of Common Market Studies. Vol. 40. No 3. P. 491-513.

Schimmelfennig F., Sedelmeier U. (2002) Theorizing EU Enlargement: Research Focus, Hypotheses, and the State of Research // Journal of European Public Policy. Vol. 9. No 4. P. 500-528.

Stefaniak B. (1998) International Cooperation of Polish Researchers with Partners From Abroad: A Scientometric Study // Scientometrics. Vol. 41. No 1. P. 155-167.

Tebbe G. (1994) Wunsch und Wirklichkeit: Das Problem der Osterweiterung // Europa-Archiv: Zeitschrift für Internationale Politik. Vol. 49. P. 389-396.

Udo L. (2015) Der unvollendete Aufholprozess der ostdeutschen Wirtschaft // Berliner Debatte Initial. Vol. 26. No 2. P. 34-49.

WPBS (2012) Cross-Border Labour Mobility between Poland-Germany. Szczecin (Poland): West Pomeranian Business School. Режим доступа: www.sb-professionals-project.eu/.../Case-Study, дата обращения 23.06.2016.

Verdun A. (2005) The challenges of European Union: Where are we today, how did we get here and what lies ahead // Eastern Enlargement: Institutional and Policy-Making Challenges / Eds. A. Verdun, O. Croci). Manchester: Manchester University Press. P. 9-23.

Zeff E.E., Pirro B.E. (2006) The European Union and the Member States. Boulder: Lynne Rienner Publishers. 